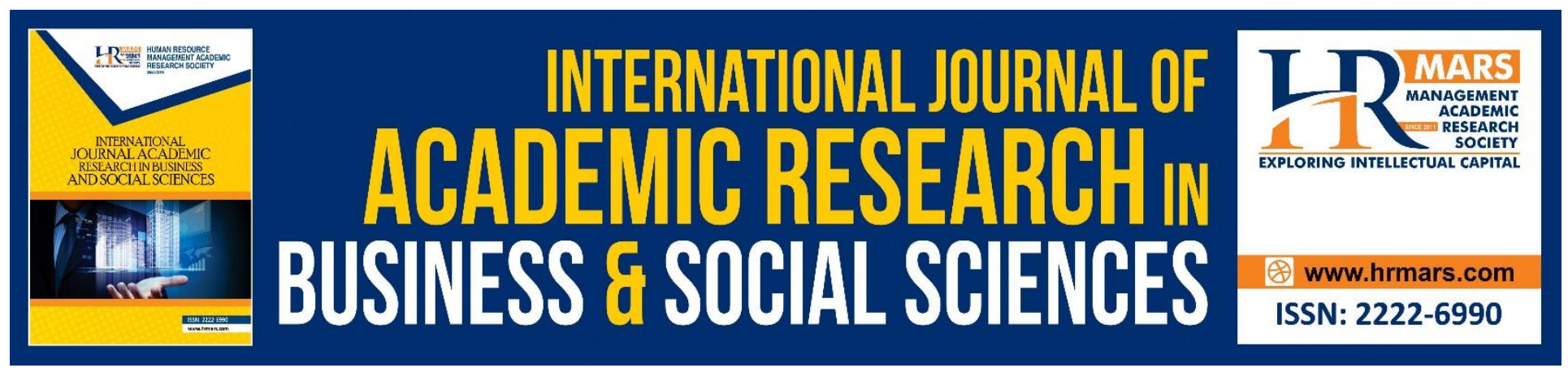

\title{
The Use of Plickers for Language Assessment of Reading Comprehension
}

\section{Easterly Anak Michael, Irina Emmanuella Anak Ejeng, Marryta Anak Udit, Melor Md Yunus}

To Link this Article: http://dx.doi.org/10.6007/IJARBSS/v9-i1/5464

DOI: $\quad 10.6007 /$ IJARBSS/v9-i1/5464

Received: 02 Jan 2019, Revised: 22 Jan 2019, Accepted: 06 Feb 2019

Published Online: 08 Feb 2019

In-Text Citation: (Michael, Ejeng, Udit, \& Yunus, 2019)

To Cite this Article: Michael, E. A., Ejeng, I. E. A., Udit, M. A., \& Yunus, M. M. (2019). The Use of Plickers for Language Assessment of Reading Comprehension. International Journal of Academic Research in Business and Social Sciences, 9(1), 637-645.

\section{Copyright: (c) 2019 The Author(s)}

Published by Human Resource Management Academic Research Society (www.hrmars.com)

This article is published under the Creative Commons Attribution (CC BY 4.0) license. Anyone may reproduce, distribute, translate and create derivative works of this article (for both commercial and non-commercial purposes), subject to full attribution to the original publication and authors. The full terms of this license may be seen at: http://creativecommons.org/licences/by/4.0/legalcode

$$
\text { Vol. 9, No. 1, 2019, Pg. } 637 \text { - } 645
$$

Full Terms \& Conditions of access and use can be found at http://hrmars.com/index.php/pages/detail/publication-ethics 


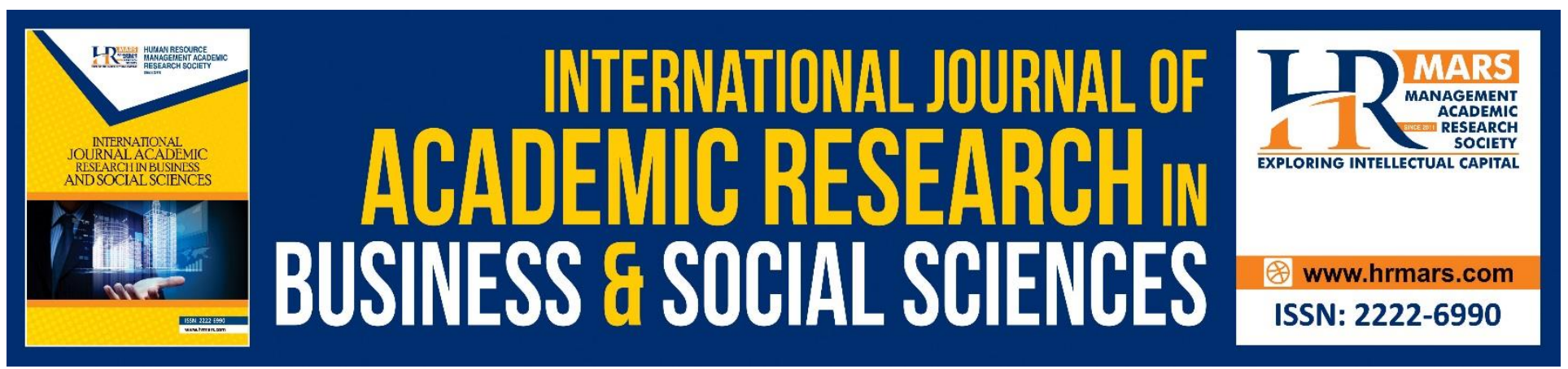

\title{
The Use of Plickers for Language Assessment of Reading Comprehension
}

\author{
Easterly Anak Michael ${ }^{1,4}$, Irina Emmanuella Anak Ejeng²,4, \\ Marryta Anak Udit 3,4 , Melor Md Yunus ${ }^{4}$ \\ SK Rancangan Sepupok ${ }^{1}$, SK Sungai Duan'2, SK Batu Niah ${ }^{3}$ \\ Faculty of Education, Universiti Kebangsaan Malaysia (UKM), 43600 Bangi, Selangor, Malaysia 4 .
}

\begin{abstract}
The 21st century of learning and teaching should always allow teachers and pupils to assess themselves. It is crucial to assess pupils' learning efficiently and give feedback to them. The assessments process can be easier and effective with the advancement of technology tools. The traditional ways of assessment burdened the implementation of assessing pupils in the classroom. Thus, language assessment can be made in an interactive way through the integration of technology tool and game. 'Plickers' is one of the technology tools for teachers to administer language assessment in an easy way inside the classroom. The purpose of this study is to analyze the use of Plickers in Language Assessment of reading comprehension among English teachers of year 3 and year 4. This study was conducted with 20 teachers from rural schools in Subis and Mukah which situated in Sarawak, Malaysia. Research design used in this study is mixed-method study. Questionnaires and structured interviews were used to collect the data. The main finding shows that the teachers agreed that Plickers helps them in assessing Reading Comprehension of year 3 and Year 4 pupils. This study concludes that Plickers can help in Language Assessment of Reading Comprehension.
\end{abstract}

Keywords: Plickers, Language Assessment, Feedback, Questionnaires, Structured interviews.

\section{Introduction}

Technology has gone through a lot of evolution and developed from simple technological tools to modern complicated tools. In this technology era, every day a new technological tool emerges and catches more advanced technology. Technology has become an essential part of our lives and makes our life easier. In other words, Information and Communication Technologies (ICT) in education has made it possible for students, teachers, and researchers to collaborate with each other in diverse ways and it also supports the modern principles of learning and language acquisition. In the 21st century learning, it is necessary to use ICT In teaching and learning process. It helps in teaching and also assessing the pupils during a lesson. Despite the emphasis of the importance of mastering the 
English language in current Malaysian Education Blueprint and 21st-century learning, the English language proficiency among rural students in Malaysia is still averagely unsatisfactory (Wreikat, Kabilan, and Abdullah, 2014). The failure rate of rural students is still high with low proficiency (Mat and Yunus, 2014). This issue is a very serious concern among educators in rural areas.

Leverage ICT to scale up quality learning across Malaysia is the seventh shifts stated in the Malaysia Education Blueprint. The Ministry of Education in Malaysia has been integrating the use of ICT in schools. Teachers implement ICT in their teaching and learning in order to increase the quality of their teaching. Apart from that, teaching has always involved assessments. A study by Yunus, Nordin, Salehi, Embi \& Salehi (2014) proved that ICT has the potential to give great impacts on the future of teachers in terms of the method of assessment. Therefore, teachers should make good use of technology to assess the understanding of the pupils. It is important to keep the pupils motivated while learning English because English in Malaysia is considered as the second language. Lim (2005) found that the use of ICT in teaching and learning allowed students to be active in finding information and build knowledge from information obtained by the chance to cross-link between knowledge of subjects without restricted by time and distance. Consequently, ICT environment will enable pupils to learn and stay motivated throughout the learning process (Yunus, Nordin, Salehi, Choo \& Embi, 2013).

The traditional ways of assessment burdened the implementation of assessing pupils in the classroom. For example in a reading lesson, teachers have to assess pupils' understanding of the lesson. If teachers use traditional assessment, it is not only time-consuming but teachers also will not get immediate feedback of pupils' understanding of the lesson. Various observations and also studies conducted discovered that many Malaysian English language teachers encounter similar challenges in teaching English. Pupils did not master the reading skill lead them to not perform well in the public examinations. Games provide a platform for teachers to attract the pupils' attention (Williyam, Yunus \& Abdul Aziz, 2016). Therefore, by assessing the pupils using Plickers, they will be more active during the lesson.

Karakuyu (2015) suggests that technology is no longer inevitable and that teachers should work on the development of techno-pedagogical content knowledge and subject to in-service training. In other words, it is suggested that teachers should start on the development of technology for educational purposes.

New technology can change the way teachers can do the assessment in the classroom. If teachers clearly see how to start using digital tools together with students, they might be more willing to use technology at a higher level in the future (Tipton \& Rich, 2015). Freeman and Tashner (2015) reached the conclusion that web-based mid-term evaluations increase students' overall achievement.

If the feedback is quick, clear and relevant, it is more likely that students will adopt this feedback into learned knowledge, correct the knowledge, and fully understand it (Freeman \& Tashner, 2015). The type of assessment should not burden the teachers' workload and the pupils should get quick feedback from the assessment.

Plickers is one of the novel audience response systems (ARS) which powered by technology. The Plickers system needs access to the Plickers website (www.plickers.com), Plickers application and a smartphone with a camera. Plickers cards are also provided for each pupil. Each Plickers card has QR- 
style design with a unique card number in the corners and each side of the QR design is labeled A, B, C, and D. 63 Plickers cards pattern can be printed from the website.

This study is to analyze the use of Plickers in assessing reading comprehension among English teachers of Year 3 and Year 4 pupils in primary schools in Subis and Mukah, Sarawak.

\section{Literature Review}

Formative assessment is the major area of interest within classrooms that "provides teachers and pupils with continuous, real-time information that informs and supports instruction" (Ramsey \& Duffy, 2016). The crucial need to modify teaching and learning to collect evidence for the purpose of improving pupil learning demanded formative assessment to be considered as a central part of classroom learning. This is to the assist formative assessment extends in leading pupils during the class time in understanding skills and concepts; in addition to making decisions about moving forward to achieve the course learning objectives. On the other hand, formative assessment yielded significant learning gains with the affordable wireless 21st-century technology that are designed to enhance pupils' learning. Altun (2015) stated that ICT is a powerful tool to teach, to motivate, and to make the subjects more interesting. It has made a great contribution to the language learning process and it has a significant impact on our education system. This has changed how teachers teach and assess, and the pupils learning. Classes are more interactive and become more pupil-centered.

Ramsey and Duffy (2016) identified two major advantages: a) supporting individualized learning, and b) opening up time in lecture courses for interactive sessions. Moreover, interest emerged in the integration of affordable tech-tools used by teachers when they use formative assessment in the classroom, e.g., Clickers, Plickers, Kahoot digital quizzes, and Socrative. Pupils can connect with the technology as the technology occupies an important place within pupils' lives. By integrating technology into the classroom, teachers are changing the way they used to teach (chalk and talk) and providing pupils with the 21st century learning the tools. This study analyzes the use of Plickers, also known as paper clickers, as one of the CRSs used for classroom formative assessment. Teachers use Plickers in different specialization around the world; for example, in courses like algebra (Damick, 2015).

According to Damick (2015), Plickers could be used for different purposes to formally assess pupils; such as for warm-up or exit tickets. Each pupil has no other option but to participate in selecting an answer. After seeing the percentage of the class and how each individual pupil performed on the question, the teacher, uses the live view tab that projects the answers from the teacher's digital device to the screen board (Damick, 2015). There is a large volume of published studies describing the effect of technology-based formative assessment on the teaching and learning process (Sheill, Lukoff, \& Mazur, 2013; Damick, 2015). However, none of the available studies covered the use of using technology for formative assessment to improve pupils' learning at the rural district of Subis and Mukah.

\section{Methodology}

\section{Research Design}

The research design used is a Mixed-Method to analyze the use of Plickers in Language Assessment of reading comprehension among the English teachers of year 3 and year 4 . Qualitative and 
INTERNATIONAL JOURNAL OF ACADEMIC RESEARCH IN BUSINESS AND SOCIAL SCIENCES

Vol. 9, No. 1, Jan, 2019, E-ISSN: 2222-6990 (C) 2019 HRMARS

quantitative data collected from questionnaires and semi-structured interviews were analyzed. The instruments were used to check the validity and reliability of the research findings.

\section{Respondents}

The respondents consist of 20 teachers from rural schools in Subis and Mukah which is situated in Sarawak. The study group for this research is the primary school teachers. The information about the teachers is presented in Table 1.

The participants of the study were examined based on gender, and district. The majority of the participants for this study are female which is 15 out of 20 and male is 5 out of 20 . In the term of the district, there are 14 out of 20 participants from Subis and 6 out of 20 participants from Mukah.

\section{Procedure}

The researchers carried out the questionnaire and structured interview after the implementation of the use of Plickers in the classroom. The questionnaire was distributed to the respondents after the class. The respondents were given one day to complete the questionnaire. The semi-structured interview sessions were carried out approximately 10 minutes after the teachers had answered the questionnaire.

The module of reading comprehension requires the pupils to read a specific text and teachers used Plickers to assess the understanding of what they are reading. The pupils used their Plickers card to answer the questions. According to the answer, they think it is true, students show the data symbols to teachers and teachers scan them with the Plickers application that has been downloaded to teachers' mobile phone. There is instant feedback to answers. In this way, teachers can share their questions with their students through the website whenever they want and have an idea about the progress of the class with the feedback they receive instantly. It will help pupils get immediate feedback of what they understand during the lesson and help teachers know what to improvise for the next lesson.

\section{Data Analysis}

The questionnaires that were analyzed and tabulated. The findings were reported by using descriptive statistic. The structured interview responses were transcribed and coded by the researchers.

\section{Findings and discussion}

(i) Questionnaire

The results of the questionnaire are presented in Table 1. Table 1 shows the descriptive statistics of the data collected from the questionnaire of teachers' perception of the use of Plickers for language assessment of reading assessment. 
INTERNATIONAL JOURNAL OF ACADEMIC RESEARCH IN BUSINESS AND SOCIAL SCIENCES

Vol. 9, No. 1, Jan, 2019, E-ISSN: 2222-6990 @ 2019 HRMARS

Table 1 Data collected from the questionnaire $(n=20)$

\begin{tabular}{|l|l|c|c|c|c|c|}
\hline No & \multicolumn{1}{|c|}{ Items } & SD & D & N & A & SA \\
\hline 1. & $\begin{array}{l}\text { Plickers makes the assessment of } \\
\text { the pupils' understanding easier. }\end{array}$ & 0 & 0 & 0 & 2 & 18 \\
\hline 2. & $\begin{array}{l}\text { I find it easy to use Plickers in the } \\
\text { class. }\end{array}$ & 0 & 0 & 0 & 3 & 17 \\
\hline 3. & $\begin{array}{l}\text { Plickers helps me to review the } \\
\text { progress of pupils' learning reading } \\
\text { comprehension. }\end{array}$ & 0 & 0 & 0 & 4 & 16 \\
\hline 4. & $\begin{array}{l}\text { Plickers helps me to inform the } \\
\text { progress of the individual learning } \\
\text { in reading comprehension. }\end{array}$ & 0 & 0 & 0 & 4 & 16 \\
\hline 5. & $\begin{array}{l}\text { It is easier to use Plickers to assess } \\
\text { reading comprehension instead } \\
\text { conventional way for assessment. }\end{array}$ & 0 & 0 & 2 & 2 & 16 \\
\hline 6. & $\begin{array}{l}\text { I will continue to use Plickers to } \\
\text { assess pupils' understanding in } \\
\text { reading comprehension. }\end{array}$ & 0 & 0 & 0 & 2 & 18 \\
\hline
\end{tabular}

As shown in Table 1, Questions 1 and 2 focused on the respondents' general view on the use of Plickers. On the other hand, Questions 3, 4, 5, and 6 targeted on the respondents' perspective about the use of Plickers in reading comprehension.

Based on Table 1, 18 out of 20 respondents are strongly agreed that "Plickers makes the assessment of the pupils' understanding easier", while 2 out of 20 respondents agreed with the item 1. It indicates Plickers makes assessment of the pupils' understanding easier. As for item 2, "I find it easy to use Plickers in the class", the respondents are 17 out of 20 strongly agreed and 3 out of 20 of the respondents agreed. It shows that it is very easy for the respondents to use Plickers in the classroom.

As for the items 3, "Plickers helps me to review the progress of pupils' learning in reading comprehension", 16 out of 20 respondents were strongly agreed and 4 out of 20 respondents were agreed. It shows that the use of Plickers helped the teachers to review the progress of pupils learning in reading comprehension.

The result of item 4 shows that 16 out of 20 respondents were strongly agreed and 4 out of 20 respondents were agreed that "Plickers helps me to inform the progress of the pupils learning individually in reading comprehension". This shows that the pupils could be informed of their progress in learning individually in reading comprehension by using Plickers.

Item 5 which focus on the statement "It is easier to use Plickers in reading comprehension instead the conventional way to assess the pupils" resulted in 16 out of 20 respondents were strongly agreed, 2 out of 20 respondents were agreed and neutral respectively. It means that the respondents prefer to use innovative tool likes Plickers compared to the conventional method to assess the pupils in reading comprehension. 
As for the item 6 in the questionnaire, "I will continue to use Plickers to assess pupils' understanding in reading comprehension" resulted in 18 out of 20 respondents was strongly agreed and 2 out of 20 respondents were agreed. This shows that the respondents will continue to use Plickers as their assessment tool in assessing pupils' understanding and progress in reading comprehension from time to time.

\section{(ii) Semi-structured Interview}

The researchers had also conducted a structured interview with all the respondents after they had answered the questionnaire. Positive feedbacks were given by the respondents. They felt happy to use Plickers in their classroom. They were interested to use Plickers in their future classroom for reading comprehension lesson. Demirkan, Gürişik, \& Akin (2017) found in their research that all of the teachers, except a teacher, liked to use Plickers in their classroom. They stated that the teachers agreed that Plickers is useful, gives instant feedback and easy to be used. They were only 2 respondents expressed that they still need to learn to use Plickers in the classroom as they found it difficult to use it in the classroom due to their low knowledge in using technology.

Other than that, the respondents also found it easy to use Plickers application. This is because the implementation of Plickers can be used both online and offline during the teaching. This makes the teachers from rural areas able to use this application even though they do not have an internet connection.

Besides that, all the respondents agreed that Plickers help them to assess and inform the pupils' understanding in reading comprehension lesson. According to Kapp as cited by Arif, Zubir, Mohamad \& Yunus (2018) in the research stated that gamification is the use of the concept of games and game mechanics to engage users. Arif et al (2018) also stated that gaming is a newly embraced phenomenon. Hence, it means that the use of Plickers helps the teachers in assessing and informing the pupils' understanding of the lesson. To conclude, the use of Plickers in language assessment of reading comprehension was successful to engage pupils actively.

\section{Conclusion}

This study concludes that the respondents agreed to the use of Plickers in assessing reading comprehension among English teachers of Year 3 and Year 4 pupils in primary schools in Subis and Mukah, Sarawak. Hence, this shows a positive impact in assessing pupils' understanding of reading comprehension classroom in a fun and stress-free way. Further studies are recommended to increase the impact of this study. It is recommended that future research would be able to implement this study with other skills in a longer period of time with a higher number of participants in both primary and secondary schools. This study should be able to use by other researchers as guidance on how to use interactive ways in assessing other skills in English language. 
INTERNATIONAL JOURNAL OF ACADEMIC RESEARCH IN BUSINESS AND SOCIAL SCIENCES

Vol. 9, No. 1, Jan, 2019, E-ISSN: 2222-6990 (C) 2019 HRMARS

\section{References}

Arif, F.K.M, Zubir, N.Z., Mohamad, M., \& Yunus, M.M. (2018). Anxiety and Kahoot Performance among Tertiary-Level Students. International Journal of Engineering \& Technology, 7 (4.21) 26-32

Altun, M., (2015). The Integration Of Technology Into Foreign Language Teaching, International Journal on New Trends in Education and Their Implications 6(1).

Damick, J. (2015). Implementing technology in an algebra classroom. M.A. Thesis, NY: State University of New York.

Demirkan, O., Gürişik, A., \& Akin, O. (2017). Teachers' Opinions About "Plickers" One Of The Online Assessment Tools. Educational Research And Practice.

Freeman, C.L. and Tashner, J. (2015). Technologies for formative assessment: can webbased applications transform the allied health science classroom and improve summative assessment outcomes.

Karakuyu, A. (2015). Bazı değişkenlerin ilköğretim sınıf öğretmenlerinin teknolojik pedagojik alan bilgilerine katkılarının incelenmesi.Yüksek Lisans Tezi, Mustafa Kemal Üniversitesi, Sosyal Bilimler Enstitüsü, Hatay.

Lim, S. C. (2005) Web learning: Effects of constructivists approach than a direct approach to the science and high-level of thinking skills. Master's diss., Universiti Sains Malaysia.

Malaysia Education Blueprint 2013-2025. (2013). Preliminary Report. Preschool to Post-Secondary Education. Ministry of Education Malaysia.

Mat, S.S.C. and Yunus M.M.(2014) Attitudes and Motivation Towards Learning English Among FELDA School Students. Aust.J Basic and Appl.Sci., 8(5):1-8

Ramsey, B., Duffy, A. (2016). Formative assessment in the classroom: Findings from three districts. Michael and Susan Dell Foundation and Education.

Schell, J., Lukoff, B., \& Mazur, E. (2013). Catalyzing learner engagement using cutting-edge response system in higher education. Cutting-Edge Technologies in Higher Education, 6. 233-261.

Tipton, T. and Rich, D. (2015). Toward a teacher friendly classroom technology implementation framework: a theory building process for the platform, activities, generate, engage and realworld (pager) model. 
Williyam, A., Yunus, M.M, and Abdul A.A (2016). Students' Perception of using Games in the Teaching of Reading Skill. International Conference on Education.Education in the $21^{\text {st }}$ century: Responding to Current Issue.

Wreikat, Y. A., Kabilan, M.K., and Abdullah, A.C.(2014). The Rural Learning Environment and Pupils' Learning of The English Language. Pertanika Journal of Social Sciences and Humanities,22(1), 3536.

Wood, T.A., Brown, K. \& Grayson, J.M., (2017). Faculty and Student Perceptions of Plickers. American Society for Engineering Education Zone II Conference.

Yunus, M.M, Nordin, N., Salehi, H.,Embi, M.A. \& Salehi, Z. (2014). Future of ICT as a pedagogical tool in ESL teaching and learning. Research Journal of Applied Sciences, Engineering and Technology,7(4),764-770.

Yunus, M.M, Nordin, N., Salehi, Choo, H.S., H.,Embi, M.A. (2013). Pro and cons of using ICT in teaching ESL reading and writing. International Education Studies,6(7), 119-130 